\title{
РОЗВИТОК ЕМОЦЙНОГО ІНТЕЛЕКТУ МАЙБУТНІХ ФАХІВЦІВ СПЕЦІАЛЬНОЇ ОСВІТИ
}

\section{Софія Березка \\ кандидат психологічних наук, доцент кафедри практичної психології}

Донбаський державний педагогічний університет

84100, Україна, м. Слов'янськ, вул. Г. Батюка, 19

berezka.sonya@gmail.com, https://orcid.org/0000-0001-8716-2712

\begin{abstract}
Анотація
Переорієнтація сучасної вищої освіти на парадигму студентоцентризму потребує перегляду змісту особистісної підготовки майбутніх фахівців. Особливого значення ця проблема набуває в межах підготовки майбутніх фахівців спеціальної освіти, де особистісна компетентність $є$ однією із провідних умов успішної професійної реалізації. Складність особистісної підготовки фахівця спеціальної освіти полягає й в тому, що перелік важливо необхідних особистісних якостей педагога має корелювати зі специфікою нозології дітей, із якими він у подальшому буде працювати. Важливими якостями в роботі майбутнього фахівця спеціальної освіти $є$ толерантність, емпатійність, емоційна стійкість, сенситивність до емоційних станів дітей, здатність вербалізувати і демонструвати власні емоції, вміти заохочувати та надихати інших. Сукупність зазначених якостей утворює такий складний феномен, як емоційний інтелект майбутнього фахівця. Емоційний інтелект (ЕI) $\epsilon$ багатокомпонентним явищем, що інтегрує внутрішньоособистісну і зовнішньоособистісну складову. Емоційний інтелект належить до ТОП-10 провідних soft skills, які забезпечують успішність професійної самореалізації. В статті висвітлено теоретичний аналіз підходів до розуміння емоційного інтелекту в психолого-педагогічній літературі, подано результати діагностики рівня розвитку емоційного інтелекту майбутніх фахівців спеціальної освіти за тестовою методикою Д. Люсіна «ЕмІн». Проведено якісний аналіз особливостей розвитку емоційного інтелекту майбутніх фахівців спеціальної освіти. 3'ясовано, що здобувачі спеціальності 016 Спеціальна освіта без цілеспрямованого формування емоційного інтелекту переважно володіють помірним і середнім рівнем розвитку ЕІ. Розкрито основні напрями змісту тренінгової програми 3 розвитку емоційного інтелекту в майбутніх фахівців спеціальної освіти. Подана програма сприяє розвитку основних складових емоційного інтелекту (ідентифікації та диференціації емоцій, сенситивності та емпатійності до інших), сприяє підвищенню емоційної стійкості здобувачів спеціальності 016 Спеціальна освіта.
\end{abstract}

Ключові слова: спеціальна освіта, підготовка майбутніх фахівців, емоційний інтелект, внутрішньоособистісний та зовнішньоособистісний емоційний інтелект

\section{Ветуп}

Сучасне реформування вищої освіти передбачає створення докорінно нового освітнього простору, орієнтованого на здобувача й на формування не лише професійних знань, умінь та навичок, але й на розвиток особистісних якостей, які забезпечать успіх його професійної діяльності. Такий підхід до підготовки майбутнього фахівця потребує інтеграції в освітні програми можливості розвитку в здобувачів так званих м'яких навичок - soft skill. 
Soft skill - це навички, які не пов'язані з конкретною професією, але допомагають гарно виконувати свою роботу й важливі для кар'єри та особистісної реалізації. Особливого значення розвиток soft skill набуває у рамках підготовки майбутніх фахівців спеціальної освіти, де особистість фахівця $€$ одним із найважливіших інструментів професійної діяльності. Про важливість особистісної підготовки фахівця спеціальної освіти зазначали такі вчені як: В. Бондар (2010), О. Бондарчук (2012), В. Синьов (2007), О. Мамічева (2011) та ін. У рамках формування особистісної готовності майбутнього фахівця важливим аспектом $\epsilon$ кореляція цієї підготовки безпосередньо з нозологією дітей, 3 якими в подальшому буде працювати спеціаліст. Сьогодні в Україні спостерігається негативна тенденція до зростання кількості дітей 3 порушеннями аутистичного спектру. Аналіз провідних показників порушень аутистичного спектру за Д. Шульженко (2009) дозволив визначити, що ключовими особистісними якостями майбутнього фахівця спеціальної освіти має бути толерантність, емоційна стійкість, вміння розпізнавати та диференціювати емоційні стани інших, емпатія. Сукупність зазначених якостей об'єднуються в інтегральному феномені - емоційному інтелекті особистості.

Вперше термін емоційний інтелект зустрічається у працях Reuven Bar-On у контексті сукупності некогнітивних здібностей, знань та компетентностей особистості (Bar-On, 2011). Подібне бачення емоційного інтелекту як сукупності певних навичок та здібностей представлено у дослідженнях P. Salovey та D. Mayer. Модель D. Mayer, P. Salovey включає три основні категорії адаптивних здібностей (Salovey \& Mayer, 1990):

- оцінювання та висловлювання емоцій;

- регулювання емоцій;

- використання емоцій у мисленні та діяльності.

Цікавим є підхід Д. Люсіна до тлумачення емоційного інтелекту. Його модель включає внутрішньоособистісний та міжоособистісний емоційний інтелект, і передбачає наявність здатності до розуміння власних та чужих емоцій, керування ними (Люсін, 2004). За Д. Люсіним, на формування ЕІ впливає безліч факторів, а його розвиток відбувається протягом усього життя особистості.

Не дивлячись на відмінності, в усіх визначеннях останніх років $є$ спільні ключові позиції. Отже, емоційний інтелект є складним інтегральним конструктом, який включає:

- здатність особистості сприймати, ідентифікувати та інтерпретувати власні емоції та емоції інших;

- здатність асимілювати емоції у думках, стимулювати за допомогою емоцій мисленнєві процеси;

- здібності до самоконтролю та саморегуляції поведінки відповідно до емоцій, що переживає особистість чи ії оточення;

- уміння використовувати усі вище зазначені здібності для побудови ефективної діяльності.

Не дивлячись на широке висвітлення проблеми емоційного інтелекту у психологопедагогічній літературі, мало вивченим залишається цей феномен у рамках підготовки майбутніх фахівців спеціальної освіти.

Мета дослідження полягає в емпіричному вивченні особливостей розвитку емоційного інтелекту майбутніх фахівців спеціальної освіти. Для реалізації поставленої мети нами було визначначено наступні завдання дослідження: 1) проаналізувати феномен емоційного інтелекту в психолого-педагогічній літературі; 2) визначити рівень 
інтелектуального розвитку майбутніх фахівців спеціальної освіти; 3) розробити програму розвитку емоційного інтелекту майбутніх фахівців спеціальної освіти.

\section{Методи дослідження}

Дослідження особливостей розвитку емоційного інтелекту майбутніх фахівців спеціальної освіти проходило протягом 2020-2021 років на базі Державного вищого навчального закладу «Донбаський державний педагогічний університет» (м. Слов'янськ, Донецька область, Україна). Дослідженням було охоплено 150 здобувачів денної та заочної форм навчання факультету спеціальної освіти ДВНЗ ДДПУ. Вік здобувачів становив від 17 до 20 років. Гендерні відмінності під час експерименту не враховувались. Усі респонденти дали добровільну згоду на анонімну участь у експерименті та мали змогу вийти з нього в будь-який момент за власним бажанням.

Експеримент проходив у декілька етапів:

- теоретико-методологічний аналіз феномену емоційного інтелекту в психологопедагогічній літературі;

- емпіричне вивчення особливостей розвитку емоційного інтелекту майбутніх фахівців спеціальної освіти на базі ДВНЗ ДДПУ;

- впровадження тренінгової програми розвитку емоційного інтелекту для здобувачів освіти факультету спеціальної освіти ДВНЗ ДДПУ;

- порівняльний аналіз отриманих даних констатувального та контрольного етапу дослідження емоційного інтелекту в майбутніх фахівців спеціальної освіти.

Для виявлення особливостей розвитку емоційного інтелекту майбутніх фахівців спеціальної освіти було використано опитувальник Д. Люсіна «ЕмІн» (Люсін, 2006). Цей опитувальник містить 46 тверджень, по відношенню до яких респондент мав висловити рівень своєї згоди. Усі твердження поєднані у п'ять субшкал, які потім сумуються у чотири шкали більш загального порядку (внутрішньоособистісний та міжособистісний емоційний інтелект, здатність до розуміння емоцій та до керування емоціями). Опитувальник дозволив продіагностувати як загальний рівень сформованості емоційного інтелекту, так і окремих його складових у конструкті (Люсін, 2006).

\section{Результати та дискусії}

Аналіз отриманих даних за опитувальником Д. Люсіна здійснювався за двома субшкалами, що вимірюють міжособистісний емоційний інтелект («розуміння чужих емоцій», «керування чужими емоціями») та за трьома субшкалами, що вимірюють різні аспекти внутрішньоособистісного емоційного інтелекту («розуміння власних емоцій», «керування власними емоціями», «особиста експресія»). Значення за шкалами обчислювалися шляхом додавання кількості набраних балів за відповідними субшкалами. Сумарна кількість балів порівнювалась зі шкалою норми за Д. Люсіним (окремо для кожного компоненту) і відповідала певному рівню сформованості того чи іншого компонента (Люсін, 2006).

Отримані результати за шкалами розуміння (РЕ) та керування емоціями (КЕ) свідчать про те, що майбутнім фахівцям зі спеціальної освіти краще дається розуміння та керування чужими емоціями - тобто здатність розуміти емоційні стани інших на основі зовнішніх проявів (міміка, жести тощо), вміння викликати емоційні реакції у інших, здатність 
співчувати емоційному стану іншої людини, а також готовності надати їй підтримку. Ці субшкали належать до міжособистісного емоційного інтелекту.

Показники за субшкалами «Розуміння власних емоцій», «Керування власними емоціями та контроль експресії» є менш вираженими, що свідчить про те, що здобувачі не завжди можуть усвідомлювати власні емоції, контролювати їх зовнішні прояви, розуміти причини їх виникнення. Дані субшкали належать до внутрішньоособистісного емоційного інтелекту.

Шкали «розуміння емоцій» та «керування емоціями» також складались з суми балів за відповідними субшкалами (розуміння власних та чужих емоцій, керування власними та чужими емоціями, відповідно). Інтегральний показник загального емоційного інтелекту розраховувся окремо для кожного досліджуваного шляхом додавання набраних ним балів за кожною субшкалою (розуміння чужих емоцій, керування чужими емоціями, розуміння власних емоцій, керування власними емоціями, керування експресією).

Загальні показники рівня сформованості емоційного інтелекту в майбутніх фахівців спеціальної освіти подано на рис. 1.

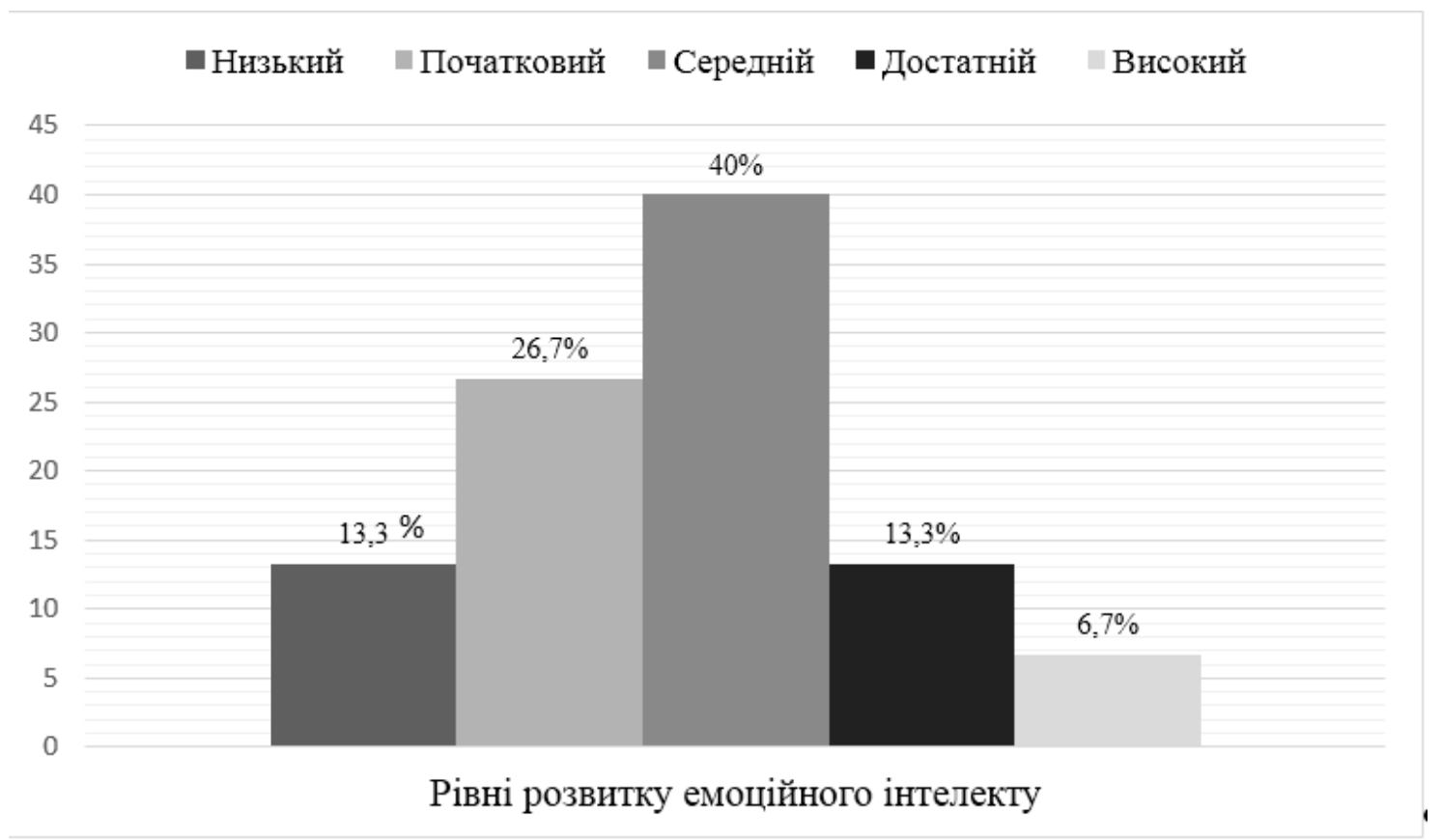

\section{Рис. 1. Рівні розвитку емоційного інтелекту майбутніх фахівців спеціальної освіти}

3 рис. 1 видно, що ми розподілили рівні сформованості загального емоційного інтелекту на п'ять рівнів. Кожен рівень встановлювався на основі зіставлення набраних балів здобувача щодо шкал норми розвитку загального ЕI за Д. Люсіним і містив такі якісні характеристики:

- високий рівень (105 і вище балів): у цю групу ввійшли здобувачі, які здатні аналізувати власні емоції та переживання, сенситивні до почуттів і поведінки інших людей; володіють здатністю з високою точністю декодувати мімічні та кінестетичні прояви емоцій; адекватно (до ситуації) висловлюють свої почуття, можуть контролювати їх; не допускають негативного впливу емоцій на процес 
спілкування і взаємодію з іншими людьми; здатні викликати довіру, надихати інших, вести за собою; вміють стимулювати ментальні процеси через емоції;

- достатній рівень (93-104 бали): здобувачі цієї групи здатні легко розпізнавати власні та чужі емоції, можуть контролювати їх у звичних обставинах. Водночас їм складніше даються процеси розуміння мотивації виникнення тих чи інших емоційних станів (як своїх, так і чужих); такі здобувачі можуть піддаватись негативному впливу емоцій, але можуть рефлексувати над своїми почуттями;

- середній рівень (79-92 бали): ці здобувачі у міжособистісних стосунках більше орієнтуються на вчинки людей, а ніж на власні уявлення; вони здатні в деяких випадках відчувати настрій інших людей і орієнтуватись у ситуації, але не завжди можуть користуватись такими здібностями; емоційні установки можуть впливати на їх реакції; володіють середнім рівнем усвідомленості власних емоцій; у повсякденному житті успішно керують власними емоціями, але при виникненні нестандартної ситуації тимчасово втрачають контроль над собою;

- початковий рівень (72-78 балів): характерний для здобувачів, які не здатні продуктивно використовувати власний емоційний досвід, не здатні бачити i розуміти емоційні стани інших людей; не аналізують емоції та поведінку інших; не схильні аналізувати власні емоції та почуття, контроль емоцій відбувається через процес їх тимчасового пригнічення;

- низький рівень (0-71 бал): притаманний для здобувачів, які не здатні диференціювати, інтерпретувати власні та чужі емоції, не вміють контролювати власні емоційні стани, у них емоції домінують над когнітивними процесами, що зумовлює некоректну поведінку по відношенню до ситуації.

Отримані дані свідчать про переважання початкового і середнього рівнів розвитку емоційного інтелекту майбутніх фахівців спеціальної освіти. 3 метою розвитку емоційного інтелекту було складено тренінгову програму для майбутніх фахівців спеціальної освіти.

Програма тренінгу 3 розвитку емоційного інтелекту здобувачів спеціальності 016 Спеціальна освіта була розрахована на 56 годин. Зміст програми передбачав формування у майбутніх фахівців таких основних здібностей:

- уміння ідентифікувати та диференціювати основні емоції та емоційні стани, здатність декодувати мімічні та кінестетичні прояви емоцій;

- уміння усвідомлювати та вербалізувати власні емоції та стани;

- здатність до емпатії, сенситивність до почуттів і поведінки інших людей;

- здатність усвідомлювати можливі причини емоційних станів співрозмовника;

- навички самоконтролю та регуляції власних емоційних станів;

- навички рефлексії;

- навички релаксації;

- навички толерантного сприйняття та комунікації;

- стресостійкість та емоційна стійкість.

Тренінгові зустрічі тривали протягом 4 годин двічі на тиждень. Усі заняття проводились за добровільної згоди здобувачів та дотриманням правил групової роботи. Заняття включали методи гештальт-терапії, трансактного аналізу, арт-терапії, психогімнастики та ігротерапії.

За результатами контрольного етапу дослідження було зафіксовано зміни кількісних і якісних показників у рівнях розвитку емоційного інтелекту майбутніх фахівців спеціальної 
освіти. Так, наприклад, відсоток здобувачів з достатнім рівнем розвитку ЕІ збільшився на 13,3\%, а кількість здобувачів з високим рівнем розвитку при повторній діагностиці склала 20\%. В майбутніх фахівців спеціальної освіти суттєво покращилась здатність до ідентифікації й диференціації емоційних станів, підвищився рівень емпатійних і сенситивних здібностей, навичок вербалізації власних емоцій.

\section{Висновки}

Проведене дослідження дозволило сформулювати такі висновки. Емоційний інтелект $\epsilon$ складним інтегральним утворенням, що включає сукупність когнітивних, поведінкових й емоційних якостей i здібностей, які забезпечують усвідомлення, ідентифікацію, диференціацію i регулювання своїх i чужих емоцій (внутрішньоособистісний та міжособистісний емоційний інтелект).

Встановлено, що ЕI у майбутніх фахівців спеціальної освіти без застосування цілеспрямованого впливу сформований переважно на середньому та початковому рівнях. Для особливостей розвитку ЕІ здобувачів спеціальності 016 Спеціальна освіта на початку їх професійної освіти характерним $є$ те, що:

- ідентифікація та диференціація емоцій відбувається переважно завдяки розумінню їх зовнішніх проявів, що зумовлює перевагу розвитку міжособистісного емоційного інтелекту над внутрішньоособистісним;

- складним є усвідомлення мотивів і чинників виникнення як своїх, так і чужих емоційних реакцій;

- недостатнє розуміння власних емоцій зумовлює труднощі в їх вербалізації та формальній рефлексії щодо емоцій та почуттів;

- розвиток процесу керування емоціями переважає над розвитком розуміння емоцій $\mathrm{i}$ вдається більш вдало, водночас при виникненні емоціогенних ситуацій вони можуть швидко втрачати контроль над власним емоційним станом.

Цілеспрямований розвиток емоційного інтелекту майбутніх фахівців спеціальної освіти дозволить сформувати провідні компоненти ЕI на достатньому і високому рівнях, що свідчить про важливість інтеграції подібних програм у освітній процес у ЗВО.

Перспективи подальшого дослідження вбачаємо в розробці програм навчальних дисциплін із елементами тренінгової діяльності, що спрямовані на розвиток провідних складових емоційного інтелекту в майбутніх фахівців спеціальної освіти.

\section{Література}

1. Бондар, В.І. (2010). Інклюзивне навчання та підготовка педагогічних кадрів для його реалізації дефектолога. Науковий часопис НПУ імені М.П. Драгоманова. Серія 19. Корекиійна педагогіка та психологія, 15, 39-42.

2. Бондарчук, O.I. (2012). Психологічна компетентність фахівця: зміст та основні підходи. Науковий вісник Миколаївського державного університету імені В.О. Сухомлинського: 3б. наук. праџь. Серія «Психологічні науки», 8, 30-35.

3. Мамічева, О. (2011). Психологічні аспекти формування професійної стійкості дефектолога. Науковий часопис Національного педагогічного університету ім. М.П. Драгоманова. Серія 19. Корекиійна педагогіка та спеціальна психологія, 19, 297301.

4. Люсин, Д.В., \& Ушаков, Д.В. (2004). Социальный интеллект: теория, измерение, исследование. Москва : Изд-во «Институт психологии РАН». 
5. Синьов, В.М. (2007). Модернізація підготовки фахівців в галузі корекційної освіти в Україні. Теоретичні та методичні засади розвитку педагогічної освіти: педагогічна майстерність, творчість, технології: збірник наукових праць, 267-270.

6. Шульженко, Д.І. (2009). Основи психологічної корекції аутистичних порушень у дітей (Монографія). Київ : Слово.

7. Bar-On, R. (2011). Emotional Intelligence: An Integral Part of Positive Psychology. South African Journal of Psychology, 40(1), 54-62.

8. Salovey, P., \& Mayer, J.D. (1990). Emotional intelligence. Imagination, cognition and personality, 9(3), 185-211.

\section{References}

1. Bondar, V.I. (2010). Inkliuzyvne navchannia ta pidhotovka pedahohichnykh kadriv dlia yoho realizatsii defektoloha [Inclusive education and training of pedagogical staff for its implementation by a speech pathologist]. Naukovyy chasopys NPU imeni M.P. Drahomanova. Seriya 19. Korektsiyna pedahohika ta psykholohiya - Scientific journal of National Pedagogical Dragomanov University. Series 19. Correctional pedagogy and psychology, 15, 39-42 [in Ukrainian].

2. Bondarchuk, O.I. (2012). Psykholohichna kompetentnist fakhivtsia: zmist ta osnovni pidkhody [Psychological competence of a specialist: content and basic approaches]. Naukovyi visnyk Mykolaivskoho derzhavnoho universytetu imeni V.O. Sukhomlynskoho: Zbirnyk naukovykh prats'. Seriya "Psykholohichni nauky" - Scientific Bulletin of Mykolayiv State University named after V.O. Sukhomlynsky: Collection of scientific works. Psychological Sciences Series, 8, 30-36 [in Ukrainian].

3. Mamicheva, O. (2011). Psykholohichni aspekty formuvannia profesiinoi stiikosti defektoloha [Psychological aspects of formation of professional stability of the defectologist]. Naukovyy chasopys NPU imeni M.P. Drahomanova. Seriya 19. Korektsiyna pedahohika ta spetsial'na psykholohiya - Scientific journal of National Pedagogical Dragomanov University. Series 19. Correctional pedagogy and special psychology, 19, 297-301 [in Ukrainian].

4. Liusin, D.V., \& Ushakov, D.V. (2004). Sotcialnyi intellekt: Teoriia, izmerenie, issledovaniia [Social Intelligence: Theory, Measurement, Research]. Moscow : In-t psikhologii RAN [in Russian].

5. Synov, V.M. (2007). Modernizatsiia pidhotovky fakhivtsiv $\mathrm{v}$ haluzi korektsiinoi osvity $\mathrm{v}$ Ukraini [Modernization of training of specialists in the field of correctional education in Ukraini]. Teoretychni ta metodychni zasady rozvytku pedahohichnoyi osvity: pedahohichna maysternist', tvorchist', tekhnolohiyi: zbirnyk naukovykh prats' - Theoretical and methodical bases of development of pedagogical education: pedagogical skill, creativity, technologies: collection of scientific works, 267-270 [in Ukrainian].

6. Shulzhenko, D.I. (2009). Osnovy psykholohichnoi korektsii autystychnykh porushen u ditei [Fundamentals of psychological correction of autistic disorders in children]. Kyiv : Slovo [in Ukrainian].

7. Bar-On, R. (2011). Emotional Intelligence: An Integral Part of Positive Psychology. South African Journal of Psychology, 40(1), 54-62.

8. Salovey, P., \& Mayer, J.D. (1990). Emotional intelligence. Imagination, cognition and personality, 9(3), 185-211. 


\title{
DEVELOPMENT OF EMOTIONAL INTELLIGENCE OF FUTURE SPECIAL EDUCATION PROFESSIONALS \\ Sofiya Berezka \\ PhD in Psyhology, Associate Professor \\ of the Department of Practical Psychology \\ Donbass State Pedagogical University \\ 19, General Batyuk Str., Slovyansk, Ukraine, 84100 \\ berezka.sonya@gmail.com, https://orcid.org/0000-0001-8716-2712
}

\begin{abstract}
Modern higher education reorientation to the paradigm of student-centeredness requires personal training content revision of future professionals. This problem acquires special significance in the framework of training future specialists in special education, where personal competence is one of the leading conditions for successful professional implementation. The complexity of personal training of a specialist in special education is that the list of important personal qualities of the teacher must correlate with the specifics of the nosology of the children with whom the teacher will work in future. Important qualities in the work of a future specialist in special education are tolerance, empathy, emotional stability, sensitivity to the emotional states of children, the ability to verbalize and convey their own emotions, to be able to encourage and inspire others. The combination of these qualities forms such complex phenomenon as the emotional intelligence of the future specialist. Emotional intelligence (EI) is a multicomponent phenomenon that integrates the intrapersonal and extrapersonal components. Emotional intelligence is in the TOP-10 leading soft skills that ensure the success of professional self-realization. The article highlights the theoretical analysis of approaches to understanding emotional intelligence in the psychological and pedagogical literature, presents the results of diagnosing the level of development of emotional intelligence of future specialists in special education by the "EmIn" test method of D. Lusin. A qualitative analysis of the peculiarities of the emotional intelligence development of future specialists in special education is given. It was found that the applicants for the specialty 016 Special Education without purposeful formation of emotional intelligence, in the vast majority, have a moderate and medium level of development of EI. The main directions of the training program content to develop emotional intelligence among future specialists of special education are presented in the article. The proposed program is determined to promote the development of the leading components of emotional intelligence (identification and differentiation of emotions, sensitivity and empathy for others), increases the emotional stability of applicants for the specialty 016 Special Education.
\end{abstract}

Keywords: special education, training of future specialists, emotional intelligence, intrapersonal and extrapersonal emotional intelligence

Подано 23.05.2021

Рекомендовано до друку 15.06.2021 